\title{
Opportunities for the utilization of natural fiber fabrics in home living textile products with the "back to nature" lifestyle trend
}

\author{
R. Febriani \\ Telkom University, Bandung, Indonesia \\ W.N.U. Bastaman \\ Universiti Sains Malaysia, Penang, Malaysia \\ M. Sutantio \\ Sekolah Tinggi Desain Indonesia, Bandung, Indonesia
}

\begin{abstract}
The lifestyle trend of "Back to Nature" is widely adopted by the people of Indonesia, especially urban residents who adopt a healthy and practical lifestyle and use natural-based products, one of which are fashion products. Many local brand designers respond to this lifestyle by creating clothing with natural fiber-based ingredients that can be used for daily activities, but this method is seen as not yet widely implemented in home living products. Therefore, the authors see a business opportunity that can be developed in the realm of the creative industries, especially home living products by adding elements of natural fiber fabric utilization and other textile craft techniques to the millennial market. This study uses a qualitative method with a business opportunity planning approach. The biggest reason for this is that the adoption of more environmentally friendly methods for the Indonesian fashion industry can be seen to provide many broad benefits.
\end{abstract}

Keywords: textile craft products, home living textile, natural fiber, lifestyle, business opportunities

\section{INTRODUCTION}

The phenomenon of environmentalism is now being carried over into the devleopment of fashion products. Thus, the concept of products being environmentally friendly has evolved into sustainable design and a sustainable fashion concept. The exposure to sustainable fashion was reinforced by Sandy Black, who said that sustainable fashion reflects the interdisciplinary nature of fashion and the complex dimensions between ethics and ecology as it occurs in the production process, consumption, marketing, and representation which often involve the opposition of priorities to be reconciled. (Black 2012). The eco-friendly method currently used by various fashion brands in Indonesia and its trend is the use of natural fiber fabric in the garment production process. Many local brand designers respond to this lifestyle by creating clothing with natural fiber base materials that can be used for daily activities. However, this adaptation is not widely applied to other sub-sectors of the fashion world, such as home living products.

The research problem is based on the conditions in which the development of the fashion industry is growing and becoming one of the country's largest economic resources, but not many designers try to explore the techniques of craft art and natural fiber fabric material when making home living products and combining them with fine art elements. With the innovation seen, there are business opportunities that can be developed and able to compete in the local market. Combining the craft of textile elements, especially in decorative elements, is a type of novelty that can be assessed as 
differentiator points of the product, so it is necessary to be the more precise business concept to fit the target market. The detail target market will be explained in the discussion section.

The purpose of this research is to create a new concept of business opportunities that maximizes product development with the utilization of natural fiber fabrics using the technique as decorative elements in home living products can be used as a reference for textile craft actors and fashions that will do business to compete with the global market and become a reference for the teaching process of new business management in textile and fashion craft.

\section{METHODOLOGY AND DISCUSSION}

The research method is carried out using the qualitative method, with data collection methods as follows.

1. Literature or review that is used in books, scientific journals, internet media, and others that discuss the merger of fashion with art, fashion with textile craft design, engineering, and mood board concepts in fashion and business start-ups.

2. Observations relating to the work that was inspired were carried out by conducting a survey.

3. Experimental methods are carried out by exploration using a variety of informal techniques, with mix materials in existing media.

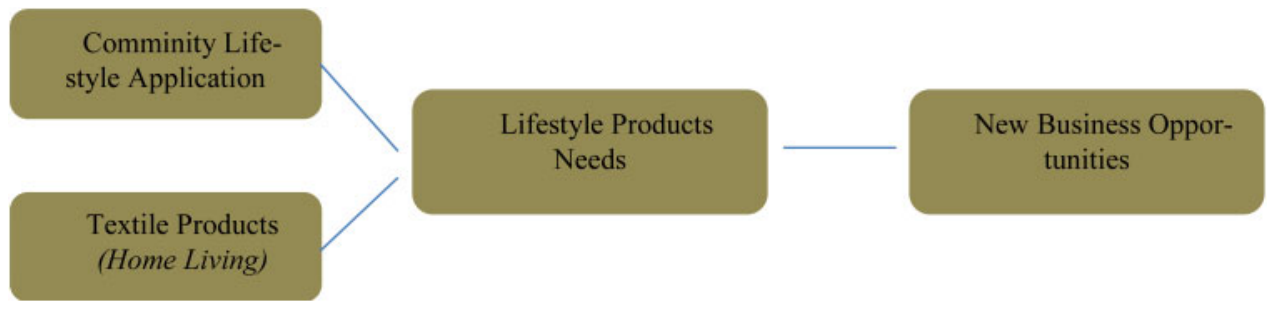

Responding to the needs of the people as consumers, the fashion industry is a creative container for producers and business owners to explore creativity with the value of the beauty of a material that has an element of identical works. The efforts of producers in shaping environmentally friendly products have begun to be seen from the emergence of several brands that use natural materials as a key ingredient in today's fashion products. The effort to fulfill the need for lifestyle also affects the dress trend. People who have an awareness to consider the aspects of quality, safety, and health tend to have an interest in clothing that uses natural fiber fabric material because it is considered more comfortable and "friendly" for body and the environment. However, nowadays the product that carries the concept of eco-friendliness is not found in home living textile products. Products that make use of natural fiber material are not only needed in fashion but on other ready-made products that can be used in the activities of daily life.

Lifestyle depicts the whole self of someone interacting with his environment. According to Kasali, market researchers who embrace lifestyle approaches tend to classify consumers based on AIO concepts, activity, interests, and opinions. In the context of activities, it can refer to areas or places where consumers do, what they buy, and how they spend their time. The community that implements the "Back to Nature" lifestyle is seen as having a fairly unique consumption behavior. Besides being identified as a group with high consumption numbers, this community also can access technology and information that is quite careful. It supports the pattern of activity with no time linkage that can be done even at home though. If further examined in its development, the residence not only serves as a place of residence but also can be a means to realize the wishes of its owners, develop works and creativity and show social status.

The application of lifestyle is not only needed in fashion but can be aligned with all products consumed daily, be it in the form of food or ready-made goods. To support the activities inside the 
Table 1. Brand references for home living textile products.

\begin{tabular}{lllll}
\hline No & Brand & Materials & Technique & Price Range \\
\hline 1 & Bermock & Acrylic \& Polyester & Woven & IDR 600.000 - IDR 800.000 \\
2 & Naratisa & Canvas \& Blacu & Pattern Making \& Digital Printing & IDR 60.000 - IDR 200.000 \\
\hline
\end{tabular}
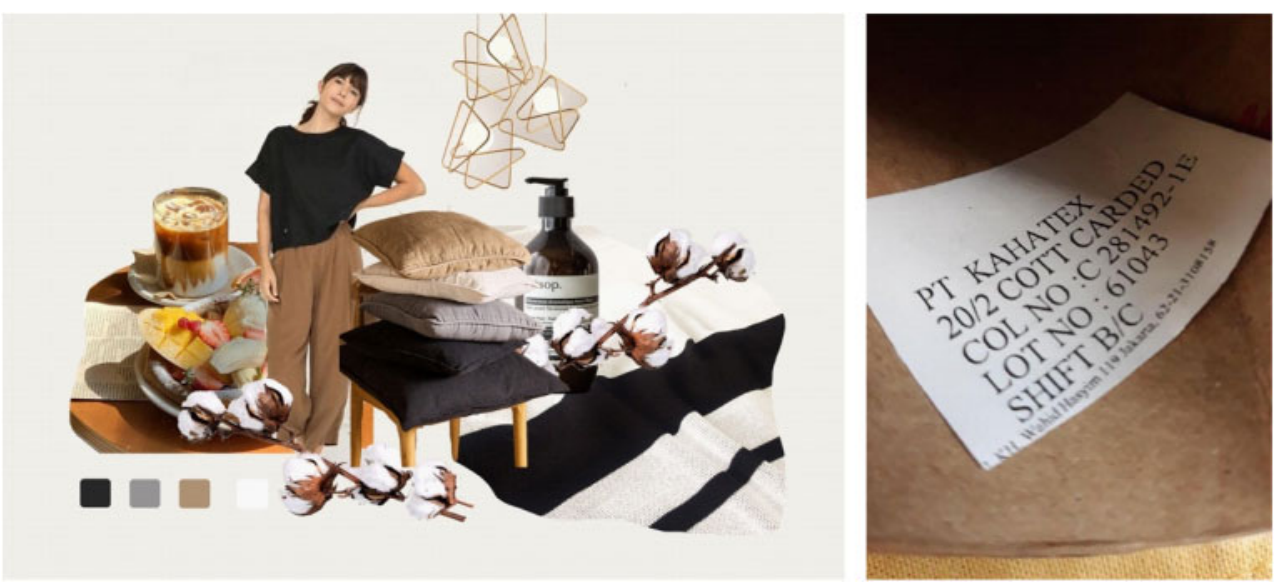

Figure 1. Mood board and proof of raw materials.

home, the product must have an environmentally friendly concept according to the pattern of consumer lifestyle. However, home living products are often do not focus on utilizing environmentally friendly materials in their textile materials.

Examples of local brands of home living products that focus on textile products are outlined in Table 1.

From the two local brands outlined in Table 1, it can be seen that the material used has not been utilizing natural fiber fabrics with environmentally friendly processing techniques. Some brands that have implemented this eco-friendly concept are found in international retail brands.

A business opportunity exists for developing home living textile products and then creating a business plan and model to introduce the products to the market. The most important aspect of such a planning step is to determine a specific market. Often, planners have a vague idea of a generalized market that their new venture could appeal to (Janowiak 1976). According to BEKRAF Statistical Data (2015), creative economic contributions are based on subsectors, with fashion ranking as the second highest with a percentage of $18.15 \%$ than in the third place in the Occupy by Kriya with a percentage of $15.70 \%$.

From the results of observation and experimentation on the natural fiber fabric material used in this research, produce a prototype of a home living textile product, first in the type of blanket product with a mood board and then detailed product knowledge as follows:

Product Detail:

- Material: $100 \%$ Cotton

- Engineering: Woven \& Tapestry

- Size: $120 \mathrm{~cm}$ x $180 \mathrm{~cm}$

- Style: Natural

\section{CUSTOMER SEGMENT}

A. Geographical: Domiciled or working in the city of Bandung, Jakarta, and Surabaya. Residing in a cluster-type residence, townhouse, or apartment, with a high-middle social status environment. 


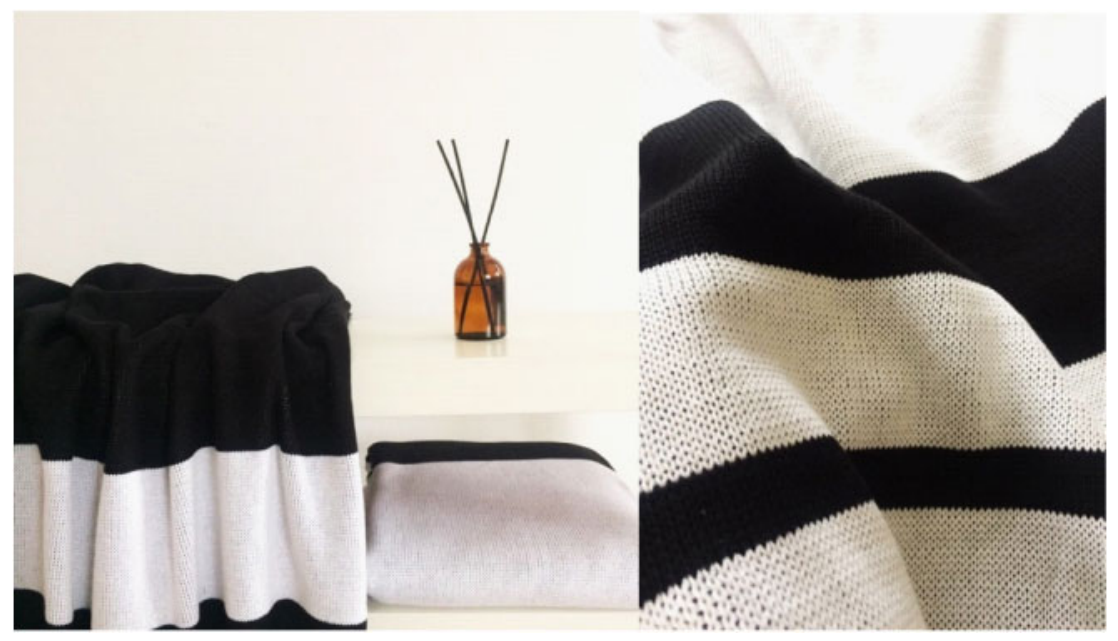

Figure 2. Home living textile prototype on knit blanket.

B. Demographic: Women/men aged 23-35 years (millennials), education level S1 or its level, working in the informal sector (freelancer, entertainer, entrepreneur, and creative industries) with a monthly income equal to management level or socio-economic status, group B and A with the main income per month around Rp. 4.600.000,-up to Rp. 8.000.000,-above.

C. Psychographic: Undergoing a healthy lifestyle or concern about environmentally friendly issues, assess a product based on the value of life in the lifestyle. Tends not to be overly exploratory in style because of the lifestyle factors that are lived, very active in the use of technology-based media.

The value offered from this product is, a local brand with an outdoor textile pricing home Living with a simple design line and natural, using natural fiber fabric material to meet the needs of the people who implement the lifestyle "Back to Nature". Observe the ethics of fashion production by considering the period of work, culture, and philosophy from the place of cloth that became the main material in the pricing is produced. In addition, the manufactured products apply structure textile techniques where similar products are more focused on the processing of color motifs. Figure 3 provides a detail mapping of the concepts of a canvas business model.

In comparison to the price of sale, this product has a selling price in the range of Rp. 600.000 - Rp 1,250,000 which is assessed to be competitive with prices in similar markets. The form of comparative analysis with the products mentioned above can be summarized in the table below:

\begin{tabular}{lll}
\hline & Strength & Weakness \\
\hline Threat & $\begin{array}{l}\text { Methods and techniques of natural } \\
\text { fiber fabric treatment can be adjusted } \\
\text { with materials used to overcome pro- } \\
\text { duction constraints and get a more } \\
\text { harmonious styling }\end{array}$ & $\begin{array}{l}\text { Home living textile products that uti- } \\
\text { lize the natural fiber fabric with the } \\
\text { value of product ethics have a limita- } \\
\text { tion of consideration toward the pro- } \\
\text { duction process to the final stage of } \\
\text { the product to attribute the problems } \\
\text { of a sumerism } \\
\text { Opportunity }\end{array}$ \\
& $\begin{array}{l}\text { Home living products especially in } \\
\text { the field of textiles that utilize natu- } \\
\text { ral fiber fabric is still minimal and has } \\
\text { not focused on the needs of consumers } \\
\text { who apply environmentally friendly } \\
\text { lifestyles. }\end{array}$ & $\begin{array}{l}\text { is still limited to several market seg- } \\
\text { mentation, and has not been widely } \\
\text { published }\end{array}$ \\
& & \\
\hline
\end{tabular}




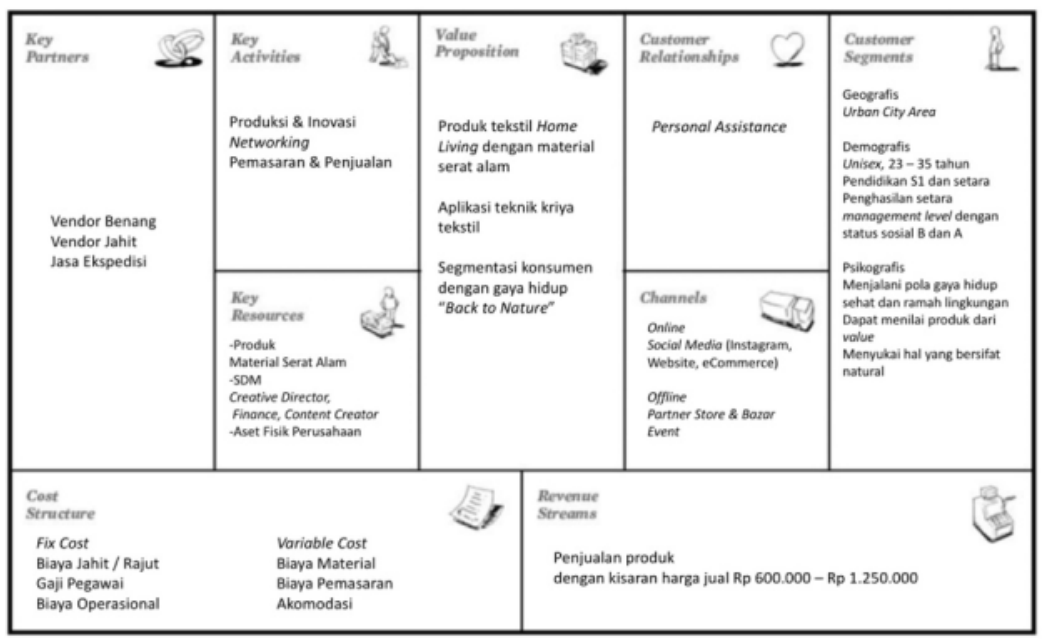

Figure 3. Home living textile products business canvas model.

\section{CONCLUSION}

The lifestyle trend "Back to Nature" is chosen because it has potential in terms of consumers' need to support an environmentally friendly lifestyle trend that has not been fully touched by most of the fashion manufacturers of home living. The lifestyle trend is applied by women ranges in ages from 23-35. But there are not many home living products that meet some aspects of the "Back to Nature" trend and support the activities of daily life patterns. The use of natural fiber materials can increase consumer interest while answering the needs of people who apply the "Back to Nature" lifestyle pattern especially in the home activities. This business opportunity can be applied to the pattern of micro-enterprises and developed by following consumer needs.

\section{REFERENCES}

Arumsari, Arini. 2018. Pemanfaatan Pewarna Alam Sebagai Trend Baru Pada Fashion Brands di Indonesia. Jurnal Rupa.

Black, Sandy. 2012. The Sustainable Fashion Handbook, London: Thames \& Hudson Ltd.

Burke, Sandra. 2013. Fashion Entrepreneur. Auckland: Burke Publishing.

David, F. R. 2009. Manajemen strategi. Edisi Kesepuluh. Jilid 1. Jakarta: Salemba Empat.

Joyce, A, and Paquin, R.L. 2016. The triple layered business model canvas: A tool to design more sustainable business models, Journal of Cleaner Production.

Prihadi, Bambang. 2006. Diktat Mata Kuliah Sejarah Seni Rupa Barat II, FBS Universitas Negeri.

Rogers, Everett M. 2003. Diffusion of Innovation Fifth Edition. USA: Free Press.

Rye, D.E. 1996. Tools For Executives Wirausahawan (Enterpreneur). Buku Pertama dan Kedua. Edisi Indonesia. Penerbit PT. Prenhalindo, Jakarta.

Yogyakarta Rangkuti, F. 2008. Analisis SWOT Teknik membedah kasus bisnis, Jakarta: Gramedia PustakaUtama. 